\title{
Enhancement of marine cloud albedo via controlled sea spray injections: a global model study of the influence of emission rates, microphysics and transport
}

\author{
H. Korhonen ${ }^{1,2}$, K. S. Carslaw ${ }^{3}$, and S. Romakkaniemi ${ }^{1}$ \\ ${ }^{1}$ Department of Physics and Mathematics, University of Eastern Finland, Kuopio, Finland \\ ${ }^{2}$ Finnish Meteorological Institute, Kuopio Unit, Kuopio, Finland \\ ${ }^{3}$ School of Earth and Environment, University of Leeds, Leeds, UK \\ Received: 23 December 2009 - Published in Atmos. Chem. Phys. Discuss.: 15 January 2010 \\ Revised: 23 April 2010 - Accepted: 26 April 2010 - Published: 3 May 2010
}

\begin{abstract}
Modification of cloud albedo by controlled emission of sea spray particles into the atmosphere has been suggested as a possible geoengineering option to slow global warming. Previous global studies have imposed changes in cloud drop concentration in low level clouds to explore the radiative and climatic effects. Here, we use a global aerosol transport model to quantify how an imposed flux of sea spray particles affects the natural aerosol processes, the particle size distribution, and concentrations of cloud drops. We assume that the proposed fleet of vessels emits sea spray particles with a wind speed-dependent flux into four regions of persistent stratocumulus cloud off the western coasts of continents. The model results show that fractional changes in cloud drop number concentration (CDNC) vary substantially between the four regions because of differences in wind speed (which affects the spray efficiency of the vessels), transport and particle deposition rates, and because of variations in aerosols from natural and anthropogenic sources. Using spray emission rates comparable to those implied by previous studies we find that the predicted CDNC changes are very small (maximum 20\%) and in one of the four regions even negative. The weak or negative effect is because the added particles suppress the in-cloud supersaturation and prevent existing aerosol particles from forming cloud drops. A scenario with five times higher emissions (considerably higher than previously assumed) increases CDNC on average by $45-163 \%$, but median concentrations are still below the $375 \mathrm{~cm}^{-3}$ assumed in previous studies. An inadvertent effect of the spray emissions is that sulphur dioxide concen-
\end{abstract}

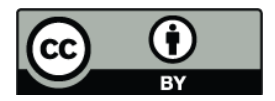

Correspondence to: $\mathrm{H}$. Korhonen (hannele.korhonen@fmi.fi) trations are suppressed by $1-2 \%$ in the seeded regions and sulphuric acid vapour by $64-68 \%$ due to chemical reactions on the additional salt particles. The impact of this suppression on existing aerosol is negligible in the model, but should be investigated further in the real environment so that inadvertent impacts can be excluded.

\section{Introduction}

Anthropogenic emissions of greenhouse gases have increased in the last decade faster than ever before (Global Carbon Project, 2008; Raupach et al., 2007). Since no quick reversal for this trend is in sight, several alternative methods to slow down global warming by deliberate manipulation of the climate have been suggested in recent years. These proposed methods, referred to as geoengineering, cover a wide range of technologies aiming to reduce either 1) the atmospheric $\mathrm{CO}_{2}$ concentration, e.g. by air capture methods (Baciocchi et al., 2006; Mahmoudkhani and Keith, 2009) or by enhancing the oceanic carbon storage (Khesghi, 1995), or 2) the amount of solar radiation absorbed in the atmosphere and the Earth's surface, e.g. by adding sulphate aerosol to stratosphere (Crutzen, 2006) or by increasing the albedo of the land surface (Akbari et al., 2009; Rigdwell et al., 2009).

In the light of current knowledge, one of the most promising geoengineering methods in terms of effectiveness and affordability is increasing the albedo of low-level marine clouds via controlled injection of sea spray particles into the atmosphere (The Royal Society, 2009; Lenton and Vaughan, 2009; Boyd, 2008). In this method, first proposed by Latham (1990), the aim is to build a fleet of unmanned,

Published by Copernicus Publications on behalf of the European Geosciences Union. 
wind-powered vessels, which could be remotely steered beneath marine clouds and emit sea water droplets into the air at a very high rate (Salter et al., 2008). A significant fraction of the released particles are expected to be transported to cloud altitude where the particles would act as cloud condensation nuclei (CCN) and thus increase the cloud droplet number concentration (CDNC) compared to an unperturbed situation. The increased CDNC would likely lead to an increased cloud albedo since the natural CDNC in remote marine stratocumulus clouds is typically fairly low $\left(<150 \mathrm{~cm}^{-3}\right)$.

Previous climate model studies have suggested that the sea spray geoengineering method could have a significant climate cooling potential. Assuming that all low-level (below $700 \mathrm{hPa}$ ) maritime clouds could be seeded with the spray vessels, Latham et al. (2008) predicted a negative cloud forcing large enough to compensate for the positive forcing from doubling the atmospheric $\mathrm{CO}_{2}$ concentration. In another study, again using imposed changes in cloud drop concentrations, Jones et al. (2009) limited geoengineering to three persistent stratocumulus regions covering 3.3\% of the Earth's surface and found that cloud seeding could offset up to $35 \%$ of current greenhouse gas forcing and delay global warming by about 25 years. Rasch et al. (2009) concluded that cloud seeding could restore global averages of temperature, precipitation or sea ice extent to present day values (but not simultaneously) even in the case of doubled $\mathrm{CO}_{2}$ concentration, assuming that it is possible to increase the CDCN to a very high value of $1000 \mathrm{~cm}^{-3}$ over the seeded areas that cover $20-70 \%$ of the world's oceans.

One limitation in all of these studies is that they do not explicitly simulate the emissions, transport or effects on natural aerosol of the injected sea spray particles, but instead set the CDNC over the seeded regions to a fixed value of $375 \mathrm{~cm}^{-3}$ or $1000 \mathrm{~cm}^{-3}$. In reality, however, sea spray geoengineering is expected to result in a spatially inhomogeneous CDNC field because of variations in aerosol dilution and deposition rates and because of the wind speed dependence of the spray rate from the planned vessels (Salter et al., 2008). The picture is further complicated by possible "inadvertent" effects on natural aerosol processes. One example of such a possible inadvertent effect is the impact of the injected sea spray particles on natural CDNC by interfering with the formation of sulphate aerosol from dimethylsulphide (DMS), which is an important source of $\mathrm{CCN}$ in the remote marine atmosphere (Korhonen et al., 2008a). Such an effect needs to be considered because freshly emitted sea spray particles can reduce the amount of gas phase sulphur compounds transported to the free troposphere (where new particle formation occurs) by two mechanisms: first, by increasing the concentration of alkaline aqueous phase in which $\mathrm{SO}_{2}$ oxidation by $\mathrm{O}_{3}$ and $\mathrm{H}_{2} \mathrm{O}_{2}$ takes place (Gurciullo et al., 1999) and second, by acting as a condensation sink for $\mathrm{H}_{2} \mathrm{SO}_{4}$ which is currently thought to be the main nucleating and condensing compound in the marine atmosphere. A further inadvertent effect is the impact of the extra sea spray particles on in-cloud supersatu- ration, which will also influence the formation of drops from existing aerosol.

In this study, we simulate the emissions and atmospheric processing of deliberately emitted sea spray particles explicitly for the first time. We quantify how wind-speed dependent geoengineering fluxes influence the $\mathrm{CDNC}$ at typical marine cloud altitudes and identify how atmospheric processes lead to spatial CDNC variations. Furthermore, we investigate how sea spray geoengineering affects the sources of natural sulphate $\mathrm{CCN}$ in the cloud seeding regions.

\section{Methods}

\subsection{Model description}

The model runs were made with the global aerosol model GLOMAP, which is an extension to the TOMCAT 3-D chemical transport model (Chipperfield, 2006; Stockwell and Chipperfield, 1999). A detailed description of GLOMAP is given in Spracklen et al. (2005). The model is run with a T42 spectral resolution $\left(2.8^{\circ} \times 2.8^{\circ}\right)$ and with 31 hybrid $\sigma-p$ levels extending to $10 \mathrm{hPa}$. Over the oceans 7 model levels represent the lowest $\sim 2 \mathrm{~km}$, of which 5 levels are in the lowest $\sim 1 \mathrm{~km}$. Large-scale atmospheric transport is specified from European Centre of Medium-Range Weather Forecasts (ECMWF) analyses at 6-h intervals. Here, the sectional version GLOMAP-bin is used, which represents the aerosol size distribution with a moving centre scheme using 20 size sections to cover the diameter range of $3 \mathrm{~nm}$ to $25 \mu \mathrm{m}$. In the runs presented here, the aerosol composition is described with three internally mixed components: sulphate, sea spray and carbonaceous aerosol (including both organic carbon (OC) and elemental carbon (EC)). The masses of all components along with the number concentration of particles are tracked in each size section. The aerosol processes simulated are: binary homogeneous nucleation of $\mathrm{H}_{2} \mathrm{SO}_{4}$ and $\mathrm{H}_{2} \mathrm{O}$ according to Kulmala et al. (1998), condensation of $\mathrm{H}_{2} \mathrm{SO}_{4}$, hygroscopic growth, coagulation, wet and dry deposition, transport, cloud processing $\left(\mathrm{SO}_{2}\right.$ oxidation by hydrogen peroxide) and sulphate formation in alkaline sea spray particles ( $\mathrm{SO}_{2}$ oxidation by ozone).

The natural sea spray emission flux is simulated according to Mårtensson et al. (2003) for particles smaller than $2 \mu \mathrm{m}$ in dry diameter and according to Monahan et al. (1986) for sizes larger than $2 \mu \mathrm{m}$. Oceanic DMS emissions are calculated using monthly mean seawater concentrations from Kettle and Andreae (2000) and the sea-to-air transfer velocity of Nightingale et al. (2000). Other simulated sources of sulfur species are anthropogenic $\mathrm{SO}_{2}$ emissions from Cofala et al. (2005) and volcanic $\mathrm{SO}_{2}$ emissions based on Andres and Kasgnoc (1998) and Halmer et al. (2002). We assume that $2.5 \%$ of $\mathrm{SO}_{2}$ from these continental sources is emitted as primary sulfate particles at particle sizes proposed by Stier et al. (2005). Primary carbonaceous emissions are 
taken from van der Werf et al. (2003) for vegetation fires and from Bond et al. (2004) for fossil and biofuels. EC/OC particles are emitted as lognormal modes at sizes proposed in the AEROCOM emissions inventory (http://nansen.ipsl.jussieu. fr/AEROCOM).

Monthly mean boundary layer (BL) cloud coverage is specified from the International Satellite Cloud Climatology Project (ISCCP) archive. Aqueous phase $\mathrm{H}_{2} \mathrm{SO}_{4}$ forms in these $\mathrm{BL}$ clouds through the reaction of $\mathrm{SO}_{2}$ and $\mathrm{H}_{2} \mathrm{O}_{2}$. Precipitation scavenging in these low-level clouds is currently not described in GLOMAP. Precipitation scavenging (in-cloud and below cloud) of particles and water-soluble gases is considered only for convective and frontal clouds as diagnosed every $6 \mathrm{~h}$ in the host model TOMCAT from the ECMWF analyses (and thus separately from ISCCP boundary layer clouds).

Sulphate formation takes place also in the alkaline aqueous sea spray particles via the reaction of $\mathrm{SO}_{2}$ and $\mathrm{O}_{3}$. This reaction is highly $\mathrm{pH}$ dependent (important only for $\mathrm{pH}>\sim 5.5$ ) and is therefore limited by the buffering capacity of the particles as sulphate is formed. It has been found that the buffering capacity of sea spray aerosol is often substantially higher compared to sea water due to calcium enrichment in the aerosol phase (Sievering et al., 1999). As we do not explicitly simulate the aqueous phase chemistry or pH in GLOMAP, we followed the approach of Gurciullo et al. (1999) who (based on ACE-1 campaign measurements) assumed that the maximum amount of sulphate formed via the $\mathrm{O}_{3}$ reaction is $6.8 \mathrm{mg}$ of sulphate per $1 \mathrm{~g}$ of dry sea spray (three times the amount compared to that without calcium enrichment). This amount is likely to be an upper limit of the actual sulphate production as it represents the maximum enhanced alkalinity observed during ACE-1.

GLOMAP-bin has been evaluated against a wide range of aerosol observations in marine and continental environments (Spracklen et al., 2007, 2008, 2009; Korhonen et al., 2008a, b) and is in good agreement. Relevant to this study, we have also shown that predicted cloud drop number concentrations are in reasonable agreement with a limited set of in situ observations in marine regions (Pringle et al., 2009).

It should be noted that in GLOMAP (as in all CTMs) changes in aerosol population do not feed back to model meteorology and cloud properties. However, the predicted aerosol fields can still be used together with information about typical marine boundary layer updrafts to calculate changes in CDNC at chosen altitudes.

\subsection{Geoengineering runs}

Three model simulations were made: an annual baseline run for the year 2000, which incorporates aerosol processes as described in Sect. 2.1, and two annual runs simulating the proposed geoengineering method by including two intensities of artificial sea spray injection. We assume a wind speed dependence of the sea spray flux based on the spraying ef-

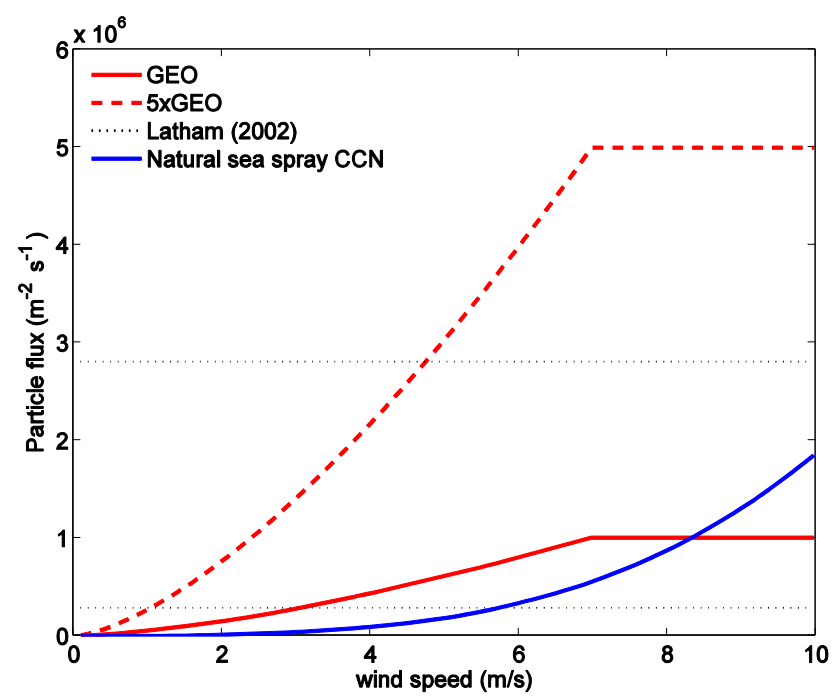

Fig. 1. Wind speed dependence of simulated geoengineering fluxes (red lines) and natural flux of sea spray particles larger than $70 \mathrm{~nm}$ (blue line). Black dotted lines show the Latham (2002) estimate range for a flux needed to produce 400 additional cloud droplets per $\mathrm{cm}^{-3}$.

ficiency of the currently planned spray vessels: Salter et al. (2008) anticipate that the vessels reach their maximum output at wind speeds of 6-8 $\mathrm{m} \mathrm{s}^{-1}$ (we assumed a threshold wind speed of $7 \mathrm{~m} \mathrm{~s}^{-1}$ in this study), and at lower speeds the spray efficiency is assumed to depend on wind speed to the power of 1.5 (S. Salter, personal communication, 2008). It should be noted that while in theory it would be ideal to produce the highest spray fluxes in low wind speed conditions, in which the background aerosol concentration is likely to be low and therefore clouds more susceptible to modification, no concrete designs of wind-driven spray vessels capable of such spray generation have been proposed. In fact, the Salter et al. (2008) design is the only one published in scientific literature to date.

The maximum particle flux at $>7 \mathrm{~m} \mathrm{~s}^{-1}$ wind speeds was based on the calculations presented in Latham (2002) for the flux required to produce $400 \mathrm{~cm}^{-3}$ additional cloud droplets. Figure 1 compares the geoengineering particle emissions used in this study (red lines) and those calculated by Latham (2002) (black dashed lines; the two lines represent the two assumptions made by Latham (2002): the top line assumes that $100 \%$ of particles sprayed at the surface activate as droplets at cloud altitude and the bottom line assumes only $10 \%$ activation) with the flux of natural CCN-sized $(>70 \mathrm{~nm})$ sea spray particles (blue line) (Mårtensson et al., 2003).

The lower of the two geoengineering particle number fluxes (hereafter: GEO) is given by

$$
\begin{array}{lll}
\mathrm{F}=5.4 \times 10^{4} \times u_{10}^{1.5}\left(\mathrm{~m}^{-2} \mathrm{~s}^{-1}\right) \quad \text { when } & u_{10}<7 \mathrm{~m} / \mathrm{s} \\
\mathrm{F}=5.4 \times 10^{4} \times 7^{1.5}=10^{6}\left(\mathrm{~m}^{-2} \mathrm{~s}^{-1}\right) & \text { when } & u_{10} \geq 7 \mathrm{~m} / \mathrm{s}
\end{array}
$$



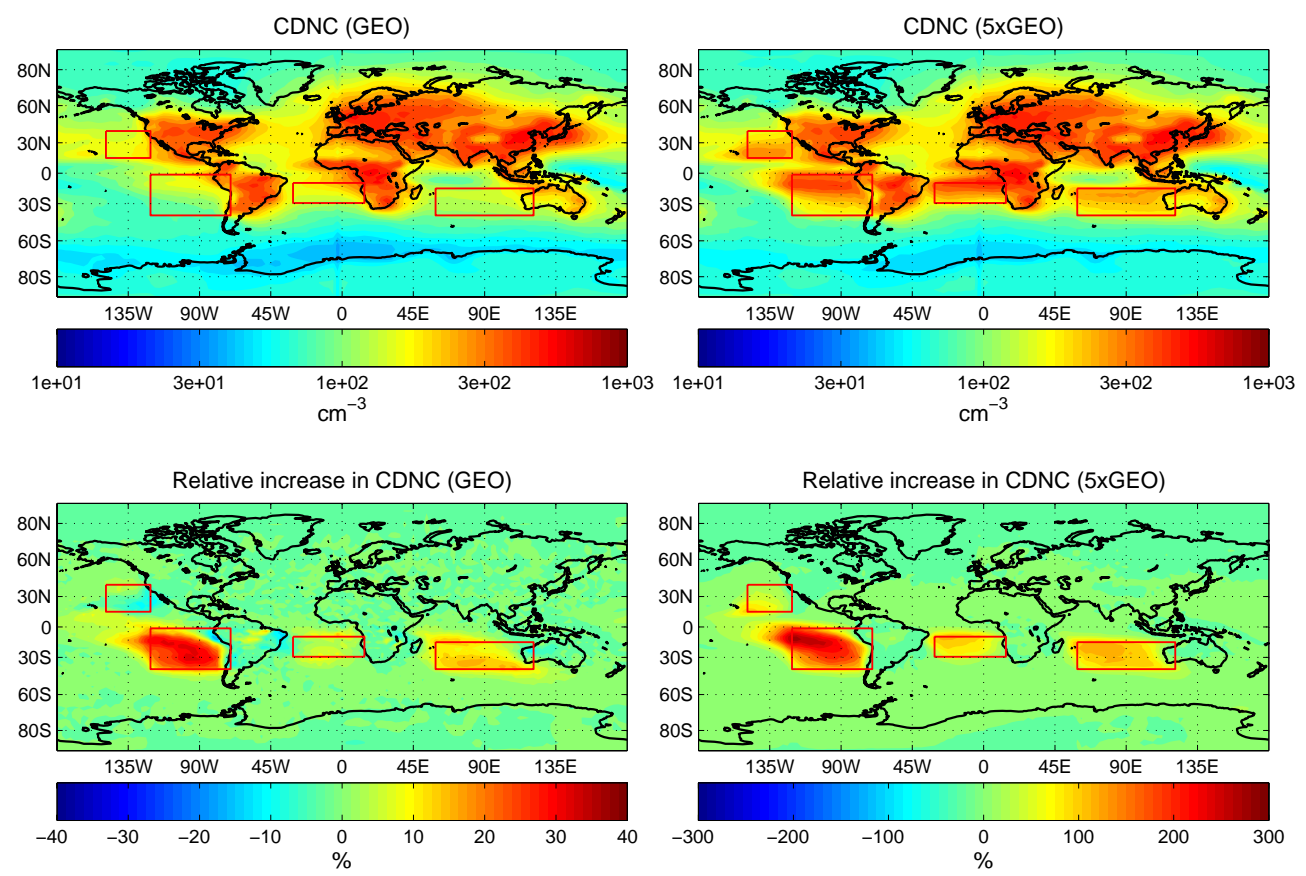

Fig. 2. Annual mean CDNC (top panels) and relative CDNC change (bottom panels) at $1 \mathrm{~km}$ altitude in GEO and $5 \times$ GEO runs.

where $u_{10}$ is the wind speed $10 \mathrm{~m}$ above the ocean surface. The higher flux (hereafter: $5 \times \mathrm{GEO}$ ) is five times the lower flux. The sea spray particles from geoengineering were emitted at a monodisperse dry diameter of $260 \mathrm{~nm}$ following Latham (2002) and corresponding to a particle dry mass of $1.5 \times 10^{-17} \mathrm{~kg}$. The particles were emitted into the lowestaltitude grid box, which over the oceans typically covers the lowest $\sim 60 \mathrm{~m}$ of the atmosphere. Once emitted, these particles underwent the same aerosol microphysical processes (i.e. coagulation, growth due to $\mathrm{H}_{2} \mathrm{SO}_{4}$ condensation and cloud processing, wet and dry deposition) and transport as the natural particles.

In both GEO and $5 \times$ GEO runs the geoengineering flux was limited to four regions: off the coast of California (North Pacific), Chile (South Pacific), Namibia (South Atlantic) and Western Australia (Indian Ocean) (Fig. 2, marine regions inside the red boxes). These regions have been identified as the most favourable all-year sites for sea spray geoengineering in earlier studies (Salter et al., 2008) and together they comprise $\sim 12.8 \%$ of the Earth's surface. Since the model spatial resolution is much too coarse $\left(2.8^{\circ} \times 2.8^{\circ}\right)$ for simulating individual clouds or even cloud decks, we did not attempt to limit geoengineering only to areas with stratocumulus clouds. Instead, cloud seeding was expected to occur continuously in all model grid cells within the chosen regions with the injection rate varying from grid to grid according to the local wind speed.

It is important to appreciate the assumptions in our study concerning the spatial homogeneity of the geoengineering spray emissions. We are assuming that it is technologically feasible to spray particles homogeneously into the atmosphere on the scale of our model grid boxes of $\sim 260 \times 260 \mathrm{~km}$ (at $30^{\circ}$ latitude) and extending over $6.5 \times 10^{7} \mathrm{~km}^{2}$ of the ocean areas in Fig. 2. A similar assumption was implicitly made by the initial proponents of this geoengineering method (Latham, 2002) when they estimated the particle flux required to alter cloud drop concentrations by a fixed amount. In reality, we believe it would be extremely challenging to spray particles homogeneously without a very large number of vessels. Inhomogeneous spraying would lead to localised high concentrations of sea spray particles and cloud drops, resulting in a different microphysical evolution of these particles compared to the homogeneous case. Clearly there is still much work required to investigate the engineering required to approach homogeneous spraying and distribution. Here we ignore these technological complications.

\section{Results}

\subsection{Predicted changes in cloud drop number concentration}

Figure 2 presents the simulated annual mean values of absolute CDNC in the geoengineering runs as well as the relative CDNC changes compared to the baseline simulation without geoengineering. The CDNC fields were calculated using the modelled monthly mean aerosol at $1 \mathrm{~km}$ altitude (approximate cloud base) and a parameterization of drop formation that takes into account the kinetic limitations of droplet growth (Nenes and Seinfeld, 2003). The updraft 
Table 1. Median CDNC concentrations and mean relative CDNC changes within the four geoengineered regions (indicated by red boxes in Fig. 2). The values are calculated from annual mean CDNC fields.

\begin{tabular}{lcccc}
\hline & \multicolumn{2}{c}{ GEO } & \multicolumn{2}{c}{$5 \times$ GEO } \\
\hline & CDNC $\left(\mathrm{cm}^{-3}\right)$ & $\Delta$ CDNC $(\%)$ & CDNC $\left(\mathrm{cm}^{-3}\right)$ & $\Delta$ CDNC $(\%)$ \\
North Pacific & 171 & -2 & 258 & 45 \\
South Pacific & 133 & 20 & 298 & 163 \\
South Atlantic & 177 & 4 & 314 & 77 \\
Indian Ocean & 134 & 11 & 246 & 96 \\
\hline
\end{tabular}
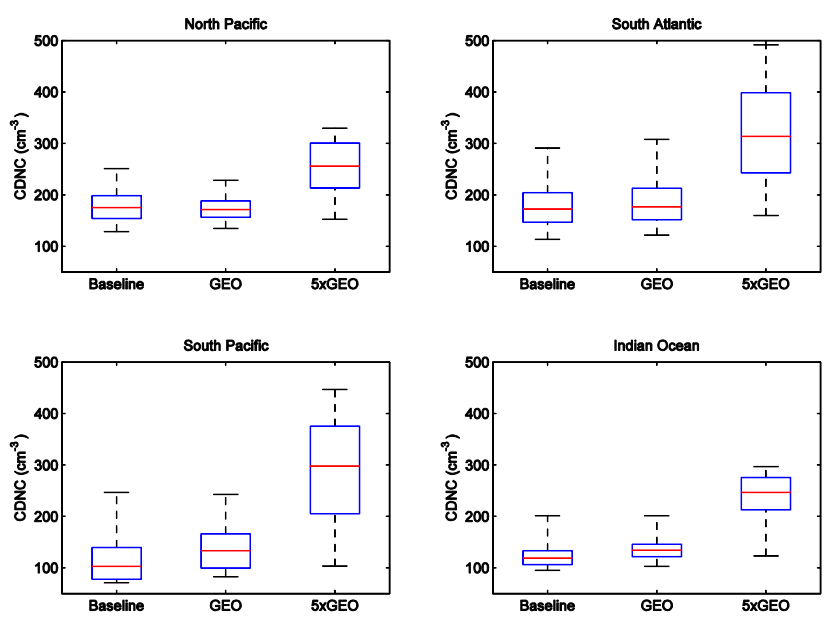

Fig. 3. The range of predicted annual mean CDNC within the four seeded regions at $1 \mathrm{~km}$ altitude. The red line indicates the median, the blue box the 25th and 75th percentiles, and the black whiskers the 5th and 95th percentiles. The number of model grid boxes in the North Pacific is 107, in the South Atlantic 131, in the South Pacific 256, and in the Indian Ocean 217.

velocities were assumed to follow a Gaussian probability distribution representing typical marine stratocumulus conditions $\left(\right.$ mean $=0 \mathrm{~m} \mathrm{~s}^{-1}$, standard deviation $\left.=0.25 \mathrm{~m} \mathrm{~s}^{-1}\right)$.

The predicted absolute CDNC varies significantly between and within the four seeded regions (Fig. 2 (top panels) and Fig. 3) which is in contradiction with the assumption of homogeneous CDNC fields over large oceanic regions in previous climate model studies (Latham et al., 2008; Jones et al., 2009; Rasch et al., 2009). The spatial variations are caused by a combination of varying emission rates (which depend on the surface wind speed), transport, and particle loss by deposition and precipitation scavenging. Because all these factors act on the aerosol population continuously, the overall correlation between the surface level wind speed and the predicted CDNC at cloud base in a model column is not very strong (Fig. 2 (top right panel) and Fig. 4), although in some regions a clear correlation is evident (e.g., the high wind speed areas of the North and South Pacific regions).
In the GEO run, the predicted CDNC in the seeded regions increases on average by $20 \%$ or less (Table 1), i.e. the sea spray injections fail to increase the CDNC substantially above typical marine background levels (Fig. 2 (top left panel) and Fig. 3). In fact, the model predicts a slight decrease in the CDNC in the North Pacific region as well as off the coast of Chile (Table 1; Fig. 2, bottom left panel). The reasons behind this quite surprising result are discussed in more detail in Sect. 3.2.

In the $5 \times$ GEO run the simulated CDNC doubles over large regions, and locally even quadruples in the tropical Pacific (Fig. 2, bottom right panel). A doubled CDNC corresponds to approximately $5 \%$ increase in cloud albedo assuming typical marine stratocumulus cloud properties (cloud thickness $500 \mathrm{~m}$, liquid water content (LWC) $0.3 \mathrm{~g} \mathrm{~m}^{-3}$ ). The simulated absolute $\mathrm{CDNC}$ in the seeded regions is in the range of $\sim 100-500 \mathrm{~cm}^{-3}$ (Fig. 2 (top right panel) and Fig. 3), the high end of which is clearly above marine background values. However, the regional median CDNCs in all four areas remain in the range of $246-314 \mathrm{~cm}^{-3}$ (Table 1), and thus on average we predict significantly lower CDNC for the spray rates considered here than the $375 \mathrm{~cm}^{-3}$ assumed in earlier climate model studies of sea spray geoengineering (Latham et al., 2008; Jones et al., 2009).

The relative CDNC change (Fig. 2, bottom panels) depends not only on the spray emission rate and transport but also on the background aerosol concentration. This can be clearly seen by comparing the seeded regions in the Indian Ocean and the North Pacific (Table 1): although the simulated absolute CDNCs in the $5 \times \mathrm{GEO}$ run are quite similar (medians $246 \mathrm{~cm}^{-3}$ and $258 \mathrm{~cm}^{-3}$ ) in both regions, the relative $\mathrm{CDNC}$ change, which in turn determines the cloud albedo change, is more than double over the Indian Ocean (96\% versus $45 \%$ over the North Pacific). This difference is because the background CDNC in the North Pacific region off the coast of polluted California is higher than over the Indian Ocean (median values $175 \mathrm{~cm}^{-3}$ and $119 \mathrm{~cm}^{-3}$, respectively). The influence of continental pollution on the relative $\mathrm{CDNC}$ change, and thus on the effectiveness of sea spray geoengineering, is also evident close to the shores in all four seeded regions (Fig. 2, bottom right panel). This result suggests that, while regions close to the continents might 


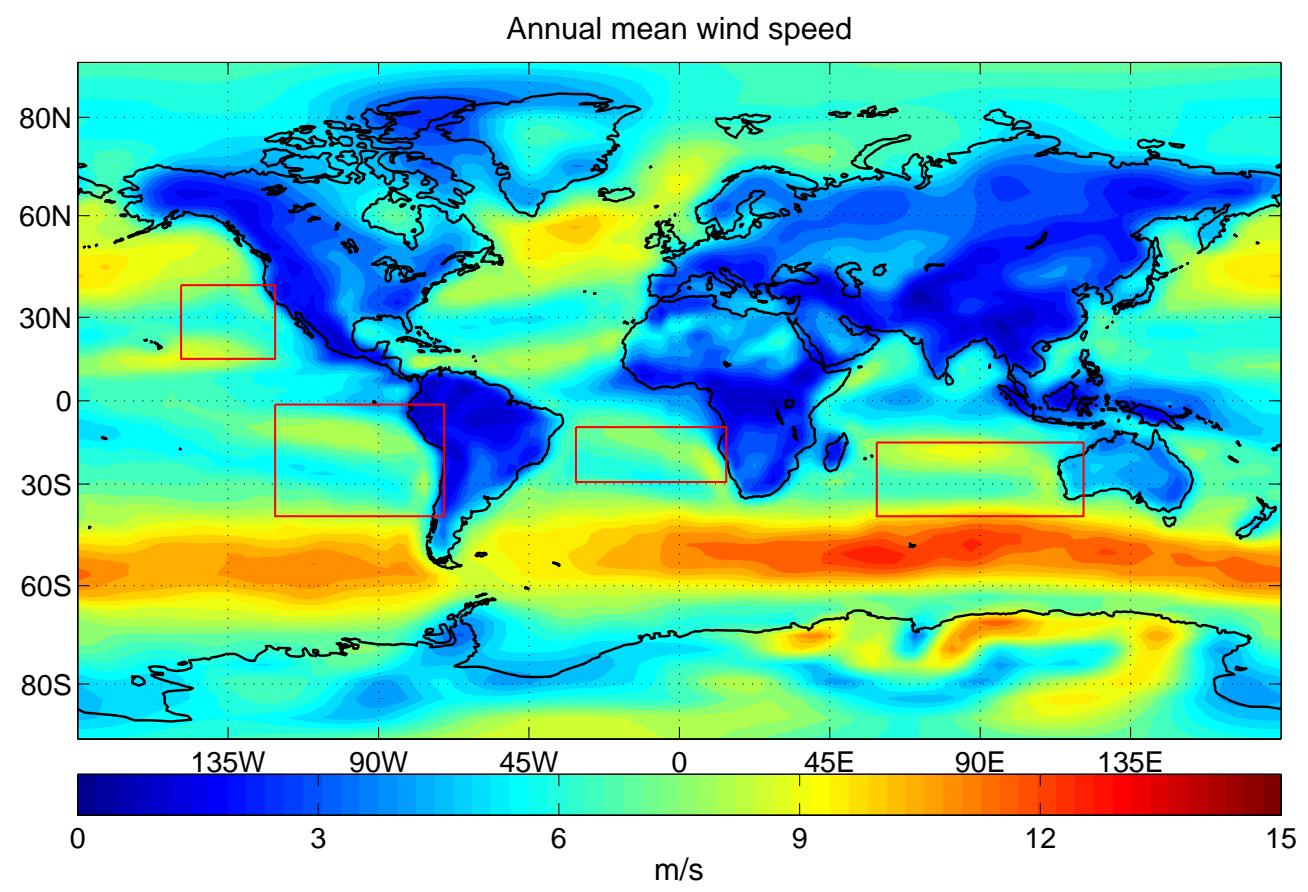

Fig. 4. Annual mean surface wind speed.

be the most preferable for cloud seeding in terms of practicality (e.g., maintenance of vessels), they are not the most favourable ones in terms of geoengineering efficiency.

\subsection{Explanation of suppressed cloud drop concentrations}

One interesting feature in the GEO simulation results presented above is the relatively small increase of CDNC in the seeded regions and even a decrease in some areas (Fig. 2, bottom left panel). The main reason behind this finding is that the injection of a high number of accumulation mode particles (dry diameter $260 \mathrm{~nm}$ ) into the aerosol population leads to an increased rate of water vapour condensation in the cloud updraughts, which reduces the maximum supersaturation reached in the cloud. Cloud model studies have previously demonstrated this effect for ship tracks (Russell et al., 1999) as well as sea spray geoengineering (Bower et al., 2006). The suppression of supersaturation means that some of the natural marine particles that form cloud droplets in the baseline run do not activate to droplets in the geoengineering runs. This effect is most significant at the lowest cloud updraughts of the Gaussian distribution we used.

Figure 5 shows the maximum supersaturation reached at $1 \mathrm{~km}$ altitude (assumed cloud base) when the updraught velocity is $0.1 \mathrm{~m} \mathrm{~s}^{-1}$. The supersaturation decreases by 0.10 0.13 percentage points from $0.20-0.26 \%$ in the baseline run to $0.10-0.14 \%$ in the GEO run. Therefore, whereas in the baseline run particles larger than $\sim 75-85 \mathrm{~nm}$ in diameter can activate as droplets, in the GEO run only particles larger than $\sim 110-140 \mathrm{~nm}$ activate. The effect is even stronger in the $5 \times$ GEO run (Fig. 5, right panel) in which the supersaturation drops by $0.14-0.20$ percentage points and only particles larger than $\sim 175-195 \mathrm{~nm}$ in diameter can form cloud droplets. However, the high number concentration of injected sea spray particles in the $5 \times$ GEO run (Fig. 6, blue line) compensates for the natural particles that do not activate, so the total CDNC increases significantly as seen in Fig. 2.

Overall, we predict reduced CDNC in more than $20 \%$ of the seeded grid boxes for updraughts less than $0.4 \mathrm{~m} / \mathrm{s}$ in the GEO run. The regional differences are, however, large: while more than half of the seeded area in the North Pacific show CDNC reduction for updraughts below $0.3 \mathrm{~m} / \mathrm{s}$, the same areal extent of reduction is not seen over the South Atlantic even at the lowest studied updraught velocity of $0.05 \mathrm{~m} / \mathrm{s}$.

It is important to note that the response of CDNC to the emitted particles requires knowledge of not only the cloud updraught velocity but also of the aerosol particle size distribution in the perturbed and unperturbed conditions. The suppression of supersaturation depends on the number, size and growth rate of the droplets. Furthermore, the effect of this suppression on the number of existing particles activated depends on the shape of the number size distribution around the cut-off (activation) diameter.

A second, although less important reason for the predicted suppressed response in CDNC in the GEO run, is that the formation of sulphate in the cloud droplets (via the reaction of $\mathrm{SO}_{2}$ and $\mathrm{H}_{2} \mathrm{O}_{2}$ ) takes place predominantly on the injected sea 

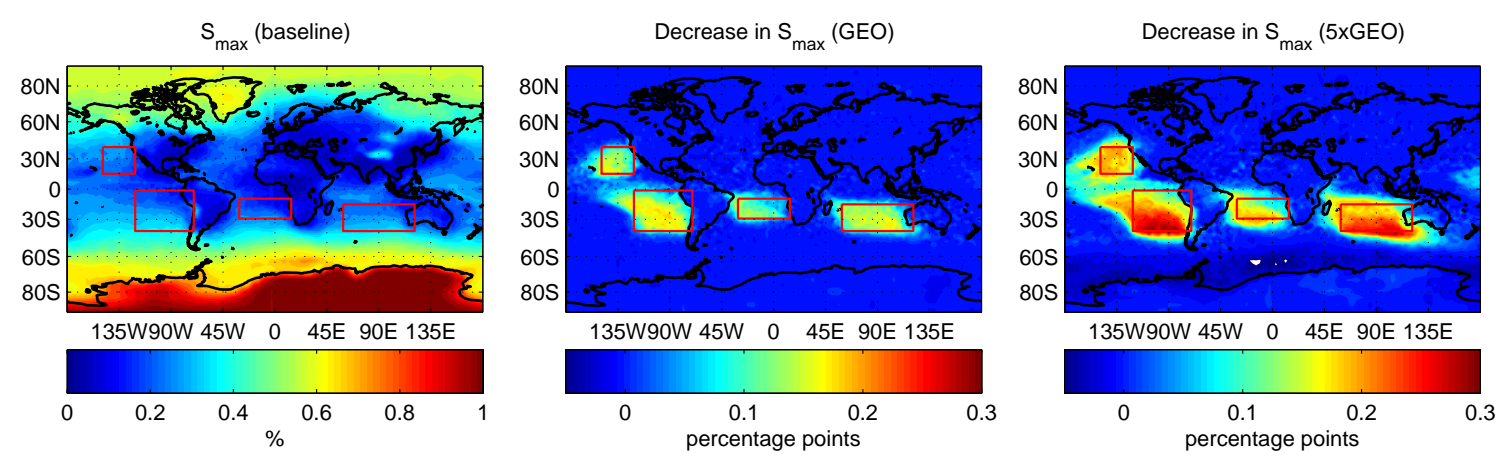

Fig. 5. Maximum supersaturation reached during cloud droplet activation at $1 \mathrm{~km}$ altitude in the baseline run (left panel) and the decrease in supersaturation caused by sea spray injections (GEO middle panel; $5 \times$ GEO right panel). All values are for updraft velocity $0.1 \mathrm{~m} / \mathrm{s}$.
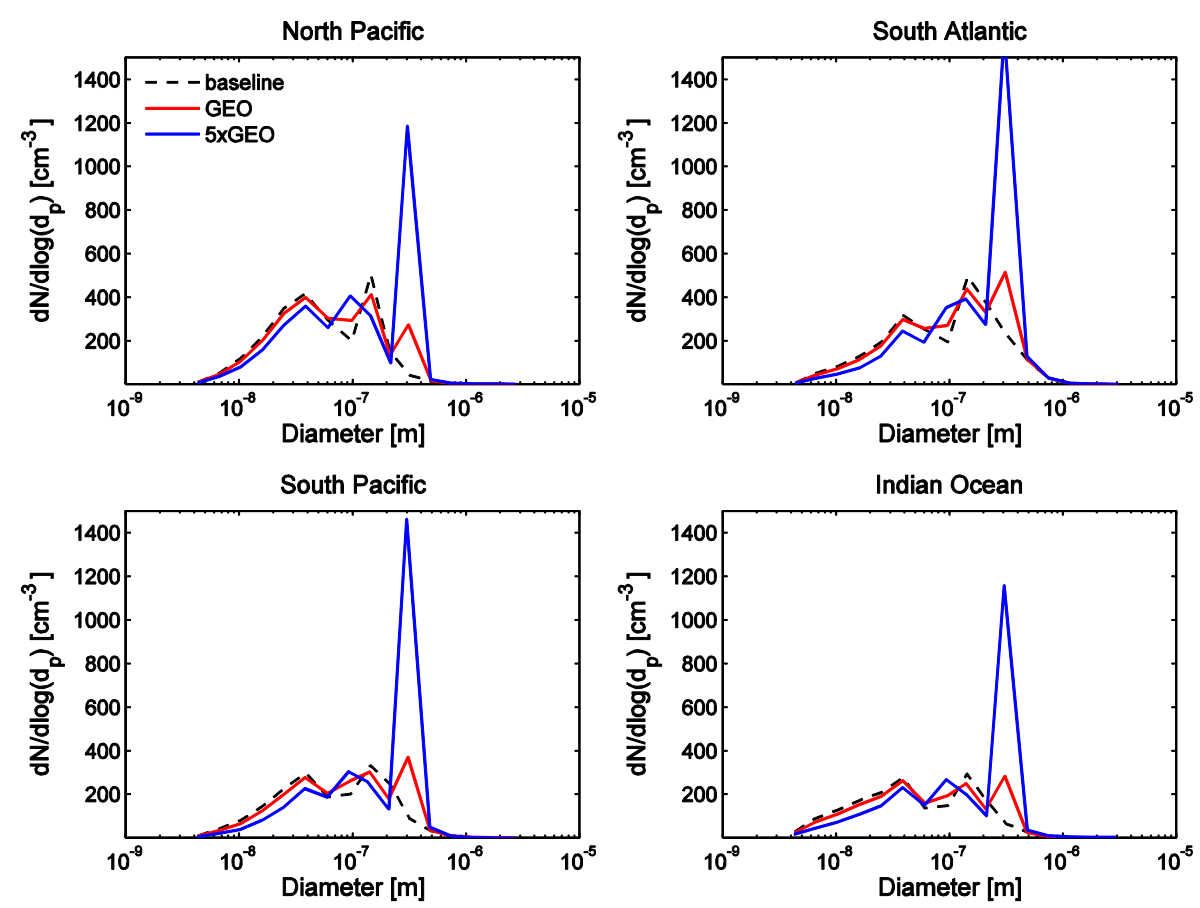

Fig. 6. Annual mean size distributions in the four geoengineered regions at $1 \mathrm{~km}$ altitude.

spray particles instead of the activated natural particles. As a result, these natural particles grow by cloud processing less rapidly than in the baseline run (Fig. 6, red and black lines). The reduced size of the natural sulphate particles (evident just above $100 \mathrm{~nm}$ diameter in Fig. 6) affects their activation to droplets during subsequent cloud cycles. Again, the effect is even stronger in the $5 \times$ GEO run (Fig. 6 , blue line) but because of the high number of injected sea spray particles, the total predicted CDNC increases.

\subsection{Effect of sea spray geoengineering on natural sulphate aerosol}

Sea spray geoengineering is expected to reduce the atmospheric concentration of sulphur-containing gases in the cloud seeding areas. The concentration of $\mathrm{SO}_{2}$ is lowered because the injected sea spray particles increase the amount of alkaline aerosol water, which is important for the $\mathrm{pH}$ dependent oxidation reaction of $\mathrm{SO}_{2}$ and $\mathrm{O}_{3}$. The increased oxidation rate of $\mathrm{SO}_{2}$ in the aqueous phase reduces its gas phase concentration, which in turn affects the gas phase reaction of $\mathrm{SO}_{2}$ and $\mathrm{OH}$ forming $\mathrm{H}_{2} \mathrm{SO}_{4}$. The concentration of $\mathrm{H}_{2} \mathrm{SO}_{4}$ is also reduced due to the increased condensation sink provided by the injected particles. The lowered 

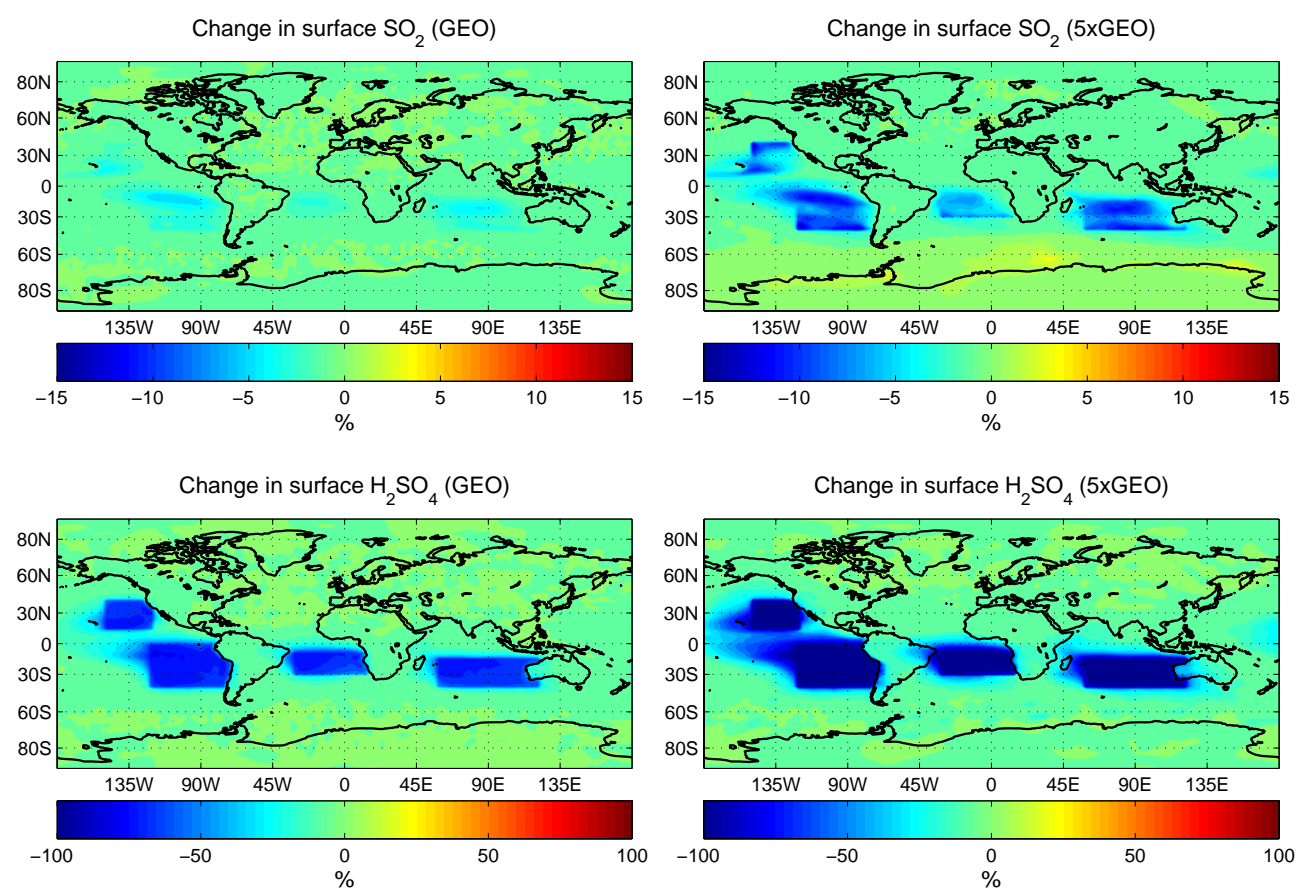

Fig. 7. Effect of cloud seeding on the annual mean surface level concentrations of $\mathrm{SO}_{2}$ (top panels) and $\mathrm{H}_{2} \mathrm{SO}_{4}$ (bottom panels).
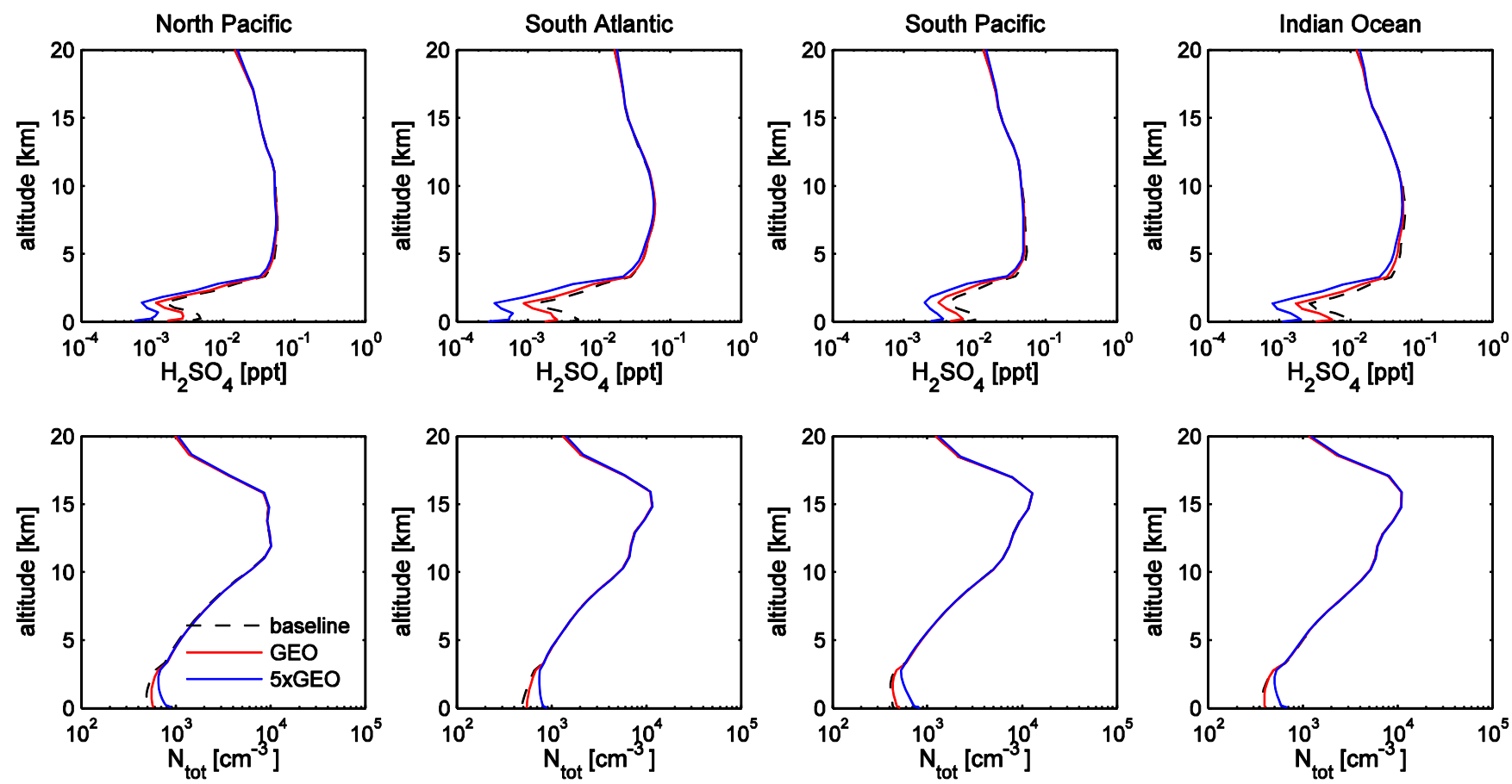

Fig. 8. Effect of cloud seeding on the annual mean vertical profiles of $\mathrm{H}_{2} \mathrm{SO}_{4}$ (top panels) and total particle number concentration ( $\mathrm{N}_{\text {tot }}$ ) in the four geoengineered regions.

concentration of $\mathrm{SO}_{2}$ and $\mathrm{H}_{2} \mathrm{SO}_{4}$ can influence the formation rate of natural sulphate $\mathrm{CCN}$ by 1) decreasing the amount of sulphur transported into the free troposphere where new particles are formed via nucleation of $\mathrm{H}_{2} \mathrm{SO}_{4}$ and $\mathrm{H}_{2} \mathrm{O}$ (Ko- rhonen et al., 2008a), and 2) decreasing the concentration of $\mathrm{H}_{2} \mathrm{SO}_{4}$ vapour that contributes to the growth of small particles to $\mathrm{CCN}$ sizes. 
Figure 7 shows the simulated relative change in surface level $\mathrm{SO}_{2}$ and $\mathrm{H}_{2} \mathrm{SO}_{4}$ in the two geoengineering runs. The effect of injected sea spray particles on the $\mathrm{SO}_{2}$ concentration is modest: we predict a 1-2\% mean decrease in the GEO run and a 5-7\% mean decrease (with local maximum decrease up to $14 \%$ ) in the $5 \times$ GEO run in the seeded areas (top panels). The reductions are fairly small because the formation of sulphate via the oxidation reaction of $\mathrm{SO}_{2}$ and $\mathrm{O}_{3}$ (effective only at $\mathrm{pH}>\sim 5.5$ ) decreases the $\mathrm{pH}$ of the aqueous phase and thus shuts off the oxidation reaction relatively rapidly. In our simulations this $\mathrm{pH}$-dependence is approximated by assuming that the oxidation reaction proceeds only when there is less than $6.8 \mathrm{mg}$ of sulphate per $1 \mathrm{~g}$ of dry sea salt in the particles. Since the mass of the injected sea spray particles (dry diameter $260 \mathrm{~nm}$ ) is small in comparison to the bulk natural sea spray mass, most of the sulphate formation takes place in the natural sea spray particles.

On the other hand, cloud seeding decreases the $\mathrm{H}_{2} \mathrm{SO}_{4}$ concentration close to the ocean surface on average by 64 $68 \%$ in the GEO run and by $96-97 \%$ in the $5 \times$ GEO run (Fig. 7, bottom panels). These large reductions are mainly due to the sea spray injections increasing the condensation sink at the surface by $28-57 \%$ and $147-304 \%$ in the two runs, respectively. Although this dramatic reduction of $\mathrm{H}_{2} \mathrm{SO}_{4}$ in the lowest atmospheric layers slows down the growth of natural ultrafine particles to larger sizes, it has only a small effect on the natural particle size distribution (Fig. 6) and CCN concentrations. This small impact is consistent with our earlier research which showed that the condensation growth of ultrafine particles is only a minor $\mathrm{CCN}$ formation pathway in the marine boundary layer (Korhonen et al., 2008a).

Furthermore, since the reduction in $\mathrm{H}_{2} \mathrm{SO}_{4}$ concentration is limited to the lowest $3-4 \mathrm{~km}$ of the atmosphere (Fig. 8, top panels), cloud seeding does not influence $\mathrm{CCN}$ formation via free tropospheric nucleation (at $\sim 5-15 \mathrm{~km}$ altitude). As a result, the vertical profile of total particle concentration remains unaffected above $4 \mathrm{~km}$ (Fig. 8, bottom panels). Below $4 \mathrm{~km}$ the change in particle number concentration is determined by the sea spray injections rather than natural sulphate particles.

\section{Conclusions}

We have presented the first model study of the efficacy of sea spray geoengineering starting from the emissions and going through to the impact on cloud drop concentrations, taking into account the full aerosol microphysical processes. We find that the wind speed dependence of the spray emissions, atmospheric transport and particle loss via deposition and precipitation scavenging lead to a spatially highly inhomogeneous CDNC. Therefore, generating nearly uniform cloud drop fields over large regions of the oceans, as has been assumed in earlier climate model studies, would be extremely challenging.
We also find that the fluxes needed to sustain the desired levels of CDNC (e.g., $375 \mathrm{~cm}^{-3}$ ) are likely to be higher than suggested in previous literature. This is because of dilution and removal of particles from the atmosphere but also because the injection of a large number of accumulation mode particles suppresses the cloud supersaturation which in turn prevents some of the natural particles from activating to cloud drops. Our results also suggest that the fractional changes in CDNC, which determine the cloud albedo change, are quite sensitive to the background aerosol concentration. Therefore, persistent stratocumulus regions close to the continents, and thus receiving significant amounts of anthropogenic pollution, may not be the most favourable locations for cloud seeding.

Since the current version of GLOMAP includes precipitation scavenging only for convective and frontal clouds (and not for BL clouds), our study is likely to underestimate the wet deposition rate of MBL particles to some extent. As a result, our estimates of the increases in CDNC due to additional spray emissions are probably an upper estimate (i.e., even higher spray fluxes would be needed to enhance CDNC). However, this effect is expected to be relatively small in the presented annual averages and does not change the conclusions of this study.

We have also been able to assess the inadvertent effects on existing aerosol, which have been neglected in earlier studies. The global model suggests that the impact of sea spray enhancement on the global sulphate aerosol system is negligible. We anticipated that suppression of $\mathrm{SO}_{2}$ and $\mathrm{H}_{2} \mathrm{SO}_{4}$ due to reactive chemistry on the particles would affect the formation of aerosol in the free troposphere, which would potentially suppress a very important $\mathrm{CCN}$ source to clean marine regions (Merikanto et al., 2009). This effect does not seem to occur, mainly because the mass of salt added to the atmosphere is relatively small and $\mathrm{SO}_{2}$ is not greatly depleted. $\mathrm{H}_{2} \mathrm{SO}_{4}$ vapour is strongly depleted in the boundary layer due to increased condensation sink, but this has a negligible effect on aerosol formation, which, in our model, occurs mostly in the free troposphere (Korhonen et al., 2008a; Merikanto et al., 2009). However, further studies of the impact of $\mathrm{H}_{2} \mathrm{SO}_{4}$ suppression on nucleation should be considered, especially taking into account the open cell structure of stratocumulus clouds.

So far the effectiveness of sea spray geoengineering has been studied only with global scale models. However, the spatial resolution in these models is poor, so they cannot resolve the aerosol emissions, transport and activation on a scale of individual stratocumulus cloud cell. Because of this limitation, there is enormous scope for studying this problem using large eddy cloud resolving models where the issues related to the spreading and entrainment of the spray into the clouds, as well as cloud microphysics, can be studied in much more detail. 
Acknowledgements. This work has been supported by the Academy of Finland's Centre of Excellence programme (decision no. 123466) and Post-doctoral researcher's project (decision no. 1118615), the Natural Environment Research Council (UK-SOLAS programme), and Maj and Tor Nessling Foundation (grant no. 2009152). We thank Corinna Hoose and Bjorn Stevens for valuable discussions.

Edited by: J. H. Seinfeld

\section{References}

Akbari, H., Menon, S., and Rosefeld, A.: Global cooling: increasing world-wide urban albedos to offset $\mathrm{CO}_{2}$, Clim. Change, 94 , 275-286, 2009.

Andres, R. and Kasgnoc, A.: A time-averaged inventory of subaerial volcanic sulfur emissions, J. Geophys. Res., 103, 2525125261, 1998.

Baciocchi, R., Storti, G., and Mazzotti, M.: Process design and energy requirements for the capture of carbon dioxide from air, Chem. Eng. Process., 45, 1047-1058, 2006.

Bond, T., Streets, D., Yarber, K., Nelson, S., Wo, J.-H., and Klimont, Z.: A technology-based global inventory of black and organic carbon emissions from combustion, J. Geophys. Res., 109, D14203, doi:10.1029/2003JD003697, 2004.

Bower, K., Choularton, T., Latham, J., Sahraei, J., and Salter, S.: Computational assessment of a proposed technique for global warming mitigation via albedo-enhancement of marine stratocumulus clouds, Atmos. Res., 82, 328-336, 2006.

Boyd, P. W.: Ranking geo-engineering schemes, Nature Geosci., 1, 722-724, 2008.

Chipperfield, M. P.: New version of the TOMCAT/SLIMCAT offline chemical transport model: Intercomparison of stratospheric tracer experiments, Q. J. Roy. Meteorol. Soc., 132, 1179-1203, 2006

Global Carbon Project: Carbon budget and trends 2007, www. globalcarbonproject.org, last access: 26 September 2008, 2008.

Cofala, J., Amann, M., Klimont, Z., and Schöpp, W.: Scenarios of world anthropogenic emissions of $\mathrm{SO}_{2}, \mathrm{NO}_{x}$, and $\mathrm{CO}$ up to 2030, Internal report of the Transboundary Air Pollution Programme, Int. Inst. Appl. Syst. Anal., Laxenburg, Austria,, 17 pp., 2005.

Crutzen, P. J.: Albedo enhancement by stratospheric sulfur injections: A contribution to resolve a policy dilemma?, Clim. Change, 77, 211-219, 2006.

Gurciullo, C., Lerner, B., Sievering, H., and Pandis, S. N.: Heterogeneous sulfate production in the remote marine environment: Cloud processing and sea-salt particle contributions, J. Geophys. Res., 104, 21719-21731, 1999.

Halmer, M., Schmincke, H., and Graf, H.: The annual volcanic gas input into the atmosphere, in particular into the stratosphere: A global data-set for the past 100 years, J. Volca. Geotherm. Res., $115,511-528,2002$

Jones, A., Haywood, J., and Boucher, O.: Climate impacts of geoengineering marine stratocumulus clouds, J. Geophys. Res., 114, D10106, doi:10.1029/2008JD011450, 2009.

Kettle, A. J. and Andreae, M. O.: Flux of dimethylsulfide from the oceans: A comparison of updated data sets and flux models, J. Geophys. Res., 105, 26793-26808, 2000
Khesghi, H. S.: Sequestering atmospheric carbon-dioxide by increasing ocean alkalinity, Energy, 20, 915-922, 1995.

Korhonen, H., Carslaw, K. S., Spracklen, D. V., Mann, G. W., and Woodhouse, M. T.: Influence of oceanic dimethyl sulfide emissions on cloud condensation nuclei concentrations and seasonality over the remote southern hemisphere oceans: A global model study, J. Geophys. Res., 113, D15204, doi:10.1029/2007JD009718, 2008a.

Korhonen, H., Carslaw, K. S., Spracklen, D. V., Ridley, D. A. and Ström, J.: A global model study of processes controlling aerosol size distribution in the Arctic spring and summer, J. Geophys. Res., 113, D08211, doi:10.1029/2007JD009114, 2008b.

Kulmala, M., Laaksonen, A., and Pirjola, L.: Parameterizations for sulfuric acid/water nucleation rates, J. Geophys. Res., 103, 83018307, 1998.

Latham, J.: Control of global warming?, Nature, 347, 339-340, 1990.

Latham, J.: Amelioration of global warming by controlled enhancement of the albedo and longevity of low-level maritime clouds, Atmos. Sci. Lett., 3, 53-58 doi:10.1006/asle.2002.0048, 2002.

Latham, J., Raasch, P., Chen, C.-C., Kettles, L., Gadian, A., Gettelman, A., Morrison, H., Bower, K., and Choularton, T.: Global temperature stabilization via controlled albedo enhancement of low-level maritime clouds, Phil. Trans. Roy. Soc. A, 366, 39693987, 2008.

Lenton, T. M. and Vaughan, N. E.: The radiative forcing potential of different climate geoengineering options, Atmos. Chem. Phys., 9, 5539-5561, 2009, http://www.atmos-chem-phys.net/9/5539/2009/.

Mahmoudkhani, M. and Keith, D. W.: Low-energy sodium hydroxide recovery for $\mathrm{CO}_{2}$ capture from atmospheric air - thermodynamic analysis, Int. J. Greehouse Gas Control, 3, 276-384, 2009.

Mårtensson, M., Nilsson, D., de Leeuw, G., Cohen, L. H., and Hansson, H.-C.: Laboratory simulations and parameterization of the primary marine aerosol production, J. Geophys. Res., 108, 4297, doi:10.1029/2002JD002263, 2003.

Merikanto, J., Spracklen, D. V., Mann, G. W., Pickering, S. J., and Carslaw, K. S.: Impact of nucleation on global CCN, Atmos. Chem. Phys., 9, 8601-8616, 2009, http://www.atmos-chem-phys.net/9/8601/2009/.

Monahan, E., Spiel, D., and Davidson, K.: A model of marine aerosol generation via whitecaps and wave disruption, in Oceanic Whitecaps and their role in air-sea exchange processes, edited by: Monahan, E. C. and MacNiocaill, G., Dordrecht, D. Reidel Publishing, 167-174, 1986.

Nenes, A. and Seinfeld, J.: Parameterization of cloud droplet formation in global climate models, J. Geophys. Res., 108, 4415, doi:10.1029/2002JD002911, 2003.

Nightingale, P. D., Malin, G., Law, C. S., Watson, A. J., Liss, P. S., Liddicoat, M. I., Boutin, J., and Upstill-Goddard, R. C.: In situ evaluation of air-sea gas exchange parameterizations using novel conservative and volatile tracers, Global Biogeochem. Cy., 14, 373-388, doi:10.1029/1999GB900091, 2000.

Pringle, K. J., Carslaw, K. S., Spracklen, D. V., Mann, G. W., and Chipperfield, M. P.: The relationship between aerosol and cloud drop number concentrations in a global aerosol microphysics model, Atmos. Chem. Phys., 9, 4131-4144, 2009, http://www.atmos-chem-phys.net/9/4131/2009/.

Rasch, P. J, Latham, J., and Chen, C.-C.: Geoengineering by cloud 
seeding: influence on sea ice and climate system, Environ. Res. Lett., 4, 045112, doi:10.1088/1748-9326/4/045112, 2009.

Raupach M. R., Marland, G., Ciais, P., Quéré, C., Canadell, J. G., and Field, C. B.: Global and regional drivers of accelerating $\mathrm{CO}_{2}$ emissions, Proc. Natl. Acad. Sci., 14, 10288-10293, 2007.

Ridgwell, A., Singarayer, J. S., Hetherington, A. M., and Valdes, P. J.: Tackling regional climate change by leaf albedo biogeoengineering, Curr. Biol., 19, 146-150, 2009.

Russell, L. M., Seinfeld, J. H., Flagan, R. C., Ferek, R. J., Hegg, D. A., Hobbs, P. V., Wobrock, W., Flossmann, A. I., O’Dowd, C. D., Nielsen, K. E., and Durkee, P. A.: Aerosol dynamics in ship tracks, J. Geophys. Res., 104, 31007-31095, 1999.

Salter, S., Sortino, G., and Latham, J.: Sea-going hardware for the cloud albedo method of reversing global warming, Phil. Trans. Roy. Soc. A, 366, 3989-4006, 2008.

Sievering, H., Lerner, B., Slavich, J., Anderson, J., Posfai, M., and Cainey, J.: $\mathrm{O}_{3}$ oxidation of $\mathrm{SO}_{2}$ in sea-salt aerosol water: Size distribution of non-sea-salt sulfate during the First Aerosol Characterization Experiment (ACE 1), J. Geophys. Res., 104, 2170721717, 1999.

Spracklen, D., Pringle, K., Carslaw, K., Chipperfield, M., and Mann, G.: A global off-line model of size-resolved aerosol microphysics; I. Model development and prediction of aerosol properties, Atmos. Chem. Phys., 5, 2227-2252, 2005, http://www.atmos-chem-phys.net/5/2227/2005/.

Spracklen, D. V., Pringle, K. J., Carslaw, K. S., Mann, G. W., Manktelow, P., and Heintzenberg, J.: Evaluation of a global aerosol microphysics model against size-resolbed particle statistics in the marine atmosphere, Atmos. Chem. Phys., 7, 2073-2090, 2007, http://www.atmos-chem-phys.net/7/2073/2007/.
Spracklen, D. V., Carslaw, K. S., Kulmala, M., Kerminen, V.M., Sihto, S.-L., Riipinen, I., Merikanto, J., Mann, G. W., Chipperfield, M. P., Wiedensohler, A., Birmili, W., and Lihavainen, H.: Contribution of particle formation to global condensation nuclei concentrations, Geophys. Res. Lett, 35, L06808, doi:10.1029/2007GL033038, 2008.

Spracklen, D. V., Carslaw, K. S., Merikanto, J., Mann, G. W. , Pickering, S., Ogren, J. A., Andrews, E., Baltensperger, U., Weingartner, E., Boy, M., Kulmala, M., Laakso, L., Lihavainen, H., Kivekäs, N., Mihalopoulos, N., Kouvarakis, G., Jennings, S. G., Birmili, W., Wiedensohler, A., Weller, R., Laj, P., Sellegri, K., Bonn, B., and Krejci, R.: Explaining global surface aerosol number concentrations in terms of primary emissions and particle formation, Atmos. Chem. Phys. Discuss., 9, 26377-26419, 2009, http://www.atmos-chem-phys-discuss.net/9/26377/2009/.

Stier, P., Feichter, J., Kinne, S., Kloster, S., Vignati, E., Wilson, J., Ganzeveld, T., Tegen, I., Werner, M., Balkanski, Y., Schulz, M., Boucher, O., Minikin, A., and Petzold, A.: The aerosolclimate model ECHAM5-HAM, Atmos. Chem. Phys, 5, 1125$1165,2005$.

Stockwell, D. and Chipperfield, M.: A tropospheric chemicaltransport model: development and validation of the model transport schemes, Q. J. Roy. Meteorol. Soc., 125, 1747-1783, 1999.

The Royal Society: Geoengineering the climate: science, governance and uncertainty, RS Policy document 10/09, Issued: September 2009, RS1636, ISBN: 978-0-085403-773-5, 2009.

van der Werf, G. R., Randerson, J. T., Collatz, G. J., and Giglio, L.: Carbon emissions from fires in tropical and subtropical ecosystems, Global Change Biol., 9, 547-562, 2003. 